\title{
Determinants of Energy Supply Security: An Econometric Analysis For Turkey
}

\author{
Enerji Arz Güvenliğini Belirleyen Faktörler: Türkiye Için Ekonometrik Bir Analiz
}

\author{
Leman ERDAL ${ }^{1}$
}

\begin{abstract}
Energy is a major input for almost all goods and services sectors; a critical foundation for economic growth and social progress. Along with social progress and economic development, energy demand is continuously increasing. Therefore, energy supply security, which means providing uninterruptible energy supply, is of vital importance for sustainable economic development. The study sheds light on concept and indicators of energy security. First We, defined the concept of energy supply security. After providing a brief literature survey on energy security, we try to investigate the main determinants of energy supply security. Accessibility, availability, affordability and acceptability are the main dimensions of energy supply security. Four indices are constructed to measure energy supply security: Import Dependency Index, Intensity Index, Domestic Production Index and Composite Index. Following a literature survey of the main determinants of supply security, and with the availability of data, an ad hoc model is formed and estimated by a Granger Causality Test and a Johansen Cointegration Analysis for the period 1970-2009 for Turkey.
\end{abstract}

Keywords: Energy Supply Security, Energy Intensity, Renewable Energy; Import Dependency; Granger Causality Test; Johansen Co-integration Analysis; Model Construction and Estimation.

\section{INTRODUCTION}

Energy is a key intermediate production factor. It plays a dominant role in providing transport,mobility and is a highly relevant final consumption good, especially in industrialised countries.

The term "energy supply security" is ubiquitous to contemporary discussion about energy issues. It has been one of the core elements in international agenda as it is closely related to micro and macroeconomic developments and also its costs are an important factor in the rate of inflation and in the international competitive position of a country's economy.

Altough the concept of "security" implies different meanings, with regard to political, military, social, economic and environmental fields; the concept of "energy security" has a broader definition including all of these categories. However economic security, is the most important one as it deals with the difficul-

\begin{abstract}
ÖZET
Enerji hemen hemen tüm mal ve hizmet sektörleri için önemli bir girdi ve ekonomik büyüme ve sosyal ilerleme için kritik bir temel intiyaçtır. Toplumsal ilerleme ve ekonomik gelişmeyle birlikte, enerji ihtiyacı da sürekli artış göstermektedir. Bu nedenle, sürdürülebilir ekonomik geliş̧me için gerekli enerji arzını, kesintisiz şekilde sağlamayı ifade eden, enerji arz güvenliği, hayati öneme sahiptir. Çalışma, enerji güveliği kavramına ışık tutmaktadır. Öncelikle enerji güvenliği kavramı tanımı yapıldı. Eneji güvenliği üzerine yapılan çalışmaları içeren literatür taramasından sonra, enerji arz güvenliğini belirleyen faktörler araştırıldı. Erişilebilirlik, kullanılabilirlik, ekonomik olma ve kabul edilebilir olma, enerji arz güvenliğinin ana boyutlarıdır. Enerji arz güvenliğini ölçmek için dört endeks geliştirilmiştir: Bağımlılık Endeksi, Yoğunluk Endeksi, Yerli Üretim Endeksi ve Bileşik Endeks. Enerji arz güvenliğini etkileyen faktörleri belirlemek amacıyla, literatürde konuyla ilgili tarama yapıldı. Illgili verilerin varlığı da dikkate alınarak; bir ad hoc model oluşturuldu. Model 1970-2009 dönemi için Granger Nedensellik Testi ve Johansen Eşbütünleşme Analiziyle tahmin edilerek, Türkiye için geçerliliği test edildi.
\end{abstract}

Anahtar Sözcük: Enerji Arz güvenliği; Yenilenebilir Enerji; Granger Nedensellik Testi; Johansen eşbütünleşme Analizi.

ties experienced by countries and necessary to predict the actions of energy agents in the international market (Löschel, 2010).

The energy prices, has always been the most important risk factor for economic security all over world due to the fact that it is threatening "energy supply security". Because, the recent concerns about "energy security" or "energy supply security" are developed and determined by energy dependency (on a single source) rate or energy import dependency (on a single courty/region) rate. The depletion of the conventional fossil fuel sources (coal, oil and natural gas) which are highly concentrated in certain regions of the world; rapidly increasing global energy demand due to social and economical growth in the past two decades and the competition over energy reserves are main factors trigger to increase energy prices. The empirical studies on energy supply security, support that affordable energy prices is a prerequisite to 
reaching decent growth rate for the national economy (Costantini et al., 2007; Shafiee and Topal, 2008). The increased oil prices have a negative effect on global oil consumption, and prices of oil substitutes, such as natural gas in the short-term. However soaring energy prices, after oil shocks, cause a decrease in energy consumption in the long-term. Besides resulting in inflation, imbalance in foreign trade as well as balance of payments, high unemployment, business loss for companies and mistrust by consumers (Costantini et al., 2007;Gnansounou, 2008; Gnansounou, 2010). Energy prices are usually important drivers of total energy demand and supply. The population size also effects the energy consumption level. That's why Ediger calls China as the "great" energy consumer with its large population. The economic extent of China has made it one of the biggest players in world energy market and moved its economy to the first row in the energy consumption ${ }^{1}$ in the world (Ediger, 2003; Sohn, 2008;).

It is suggested that it would be a sounder approach to analyse energy supply security in terms of economic, geographical and political perspectives that are complementary to explain the 1973 OPEC petrol crisis, which was partially provoked by the Arab-Israel conflict and cannot be explained by a merely economic model. (Ediger, 2003; Ediger, 2009; Erdal, 2011).

The concept of energy supply security has been a core mission as effects both today's strong and sustained economic development as well as welfare of the future generations. Ediger (2003) associates energy security with sustainable energy and defines it as "ability to meet today's energy needs, without harming future generations to meet their own". The intergenerational energy concept, is an indicator of socio-economic development and a significant subject in need of thorough and multi-dimensional investigation.

Energy is of vital importance as a factor of production in the micro scale as well as a necessity for the economic growth and social development of a country. However it has not been thoroughly studied in general economics, political economics, developmental economics and international economics. This study, aims to cover one of the shortcomings of energy economics in this area by makign an interdisciplinary study on all the above-mentioned subjects.

The purpose of this study is to contribute to the literature about the conceptualisation of energy supply security, by attempting to measure energy supply security and by approaching the affecting factors and, testing these for Turkey with times series analyses.

The article is structured within three sections. The first section includes definitions of the concept of energy suppy security and a literature survey about energy security. While some of these studies are theoretical and some others include empirical analyses. In this section, four indices are constructed to measure energy supply security: Dependency Index, Intensity Index, Domestic Production Index and Composite Index. Following a literature survey on the definition and main determinants of supply security has been made. Than an ad hoc model is formed, with the availability of data, by using petroleum prices, total primary energy supply, energy consumption per capita, share of renewable energy sources and carbon dioxide emissions. The potential factors are detected and estimation methods are discussed; furthermore, the model(s) is created for estimation by means of graphical and descriptive analyses. Thus the factors affecting energy supply security are studied by an econometric analysis.

A concluding section finally draws some important points, gives some policy implications of the study and the concept of energy security.

\section{DEFINITIONS AND LITERATURE REVIEW ON ENERGY SUPPLY SECURITY}

The concept of "energy supply security" refers to the ability to reach an existing energy source, rather the depletion of potential sources. The availability of energy sources, especially renewable, is a critical issue for energy supply security due to an unequally distribution of fossil fuels on the world. The definition also includes sustainability of a reliable, affordable energy supply within both short-term and long-term (Gnansounou, 2010; Chester, 2010).

Many more factors ranging from having domestic resources to energy imports dependency can influence the security of energy supply. There are also some other approaches such as "market-centered" definitions which aim to assess the market risks quantitatively as wel as qualitatively. However given that the focus mostly is on the security of external supply and energy security index which includes assesment of import dependency and geopolitics (Chester, 2010).

The energy supply security indicators are created by using the parameters used for defining the concept of "energy security". The studies on security of energy supply (ESS) are usually trying to define the concept, asses and evaluate the causes, dimensions and indicators of the economic vulnerability of economies facing the risk of energy supply disruptions. 
While some of these studies are theoretical, some others include empirical analyses (which are summarized in Table 2.1.).

Models, which measure the degree of energy security against the risk of energy supply disruptions, are generally divided into two groups. While the first group analyses the factors which cause vulnerability of the economy (such as energy prices); the second group explains the size of the vulnerability. The results of such kind of macroeconomic models are effective and reliable references used by policymakers who tries to reduce economic vulnerability against any energy supply disruptions. Macroeconomic Models are also divided into two types; as Multivariate Time Series Models (TSM) and General Equilibrium Models (CGE) (Jansen, 2004;Gnansounou, 2010).

While some studies use energy supply security indexes which are created for each country's energy sources and some others use indexes which make a comparison between two/more countries' vulnerability against supply disruptions. Generally ShannonWeiner and Herfindahl-Hirschmann indexes have been used to measure the degree of energy security or vulnerability against the risk of any energy supply disruption. The International Energy Agency (IEA) has used Herfindahl-Hirschmann and developed indicators which measure intensity or market share of energy sources (oil, coal and natural gas) and vulnerability or sensitivity level of an economy against the risk of supply disruption whose import dependency is significantly high (Kruyt et al., 2009).

Löschel (2010) divides indicators into two groups as ex post and ex ante. The ex-post approach investigates the economic impact of the energy system used in the past. The ex-ante approach investigates the future effects of the energy system on the economy by using current market conditions. While the ex-post approach is related to the price and amount of energy; the ex-ante approach is related to the market structure, global political events or technological progress which will affect the supply and demand of global energy consumption and productivity.

The Modified Shannon-Wiener index, which was first developed in the 2000's, has been used to construct the indicators of energy diversity, import dependency, primary energy demand and political stability. Another quantitative indicator is the index constructed by using a Principal Component Analysis and developed against oil supply disruption which measures the vulnerability of the economy (Jansen, 2004). In a similar way, Constantini et al. (2007) group the energy supply security indicators into two; as physical indicators and economic, indicators which are defining dependency and vulnerability. Le Coq and Paltseva (2009) attempt to define the short-term energy supply risks by creating separate indices for the primary energy resources such as oil, natural gas and coal and by combining the economic effects of energy import diversification, the political risks in the supplier country and energy supply interruption during energy transfer. Some other studies measuring economic vulnerability against energy supply disruption were carried out by Gupta (2008), and Gnansounou (2008). Besides, Badea et al. (2011) attempted to measure energy supply security by using a set of eight individual indicators (ID); are energy concentration; carbon concentration; import dependency rates of oil; natural gas and coal; primary energy production; electrical production capacity and the energy demand by transport sector. They tried to build the Composite Indicator $(\mathrm{Cl})$ and used more for illustrative purposes, even if these indicators covered dimensions of energy security, such as demand, supply, environmental aspects and might not be considered as the optimal set of IDs. World Energy Council has developed the composite vulnerability index in order to observe the European countries' capacity to struggle against long term energy vulnerability (Gnansounou, 2010; Gnansounou, 2008). Following some more empirical researchs on energy supply security are summarized in Table 2.1. 
Table:2.1 Empirical Studies on Energy Supply Security

\begin{tabular}{|c|c|c|c|c|}
\hline Author and Year & $\begin{array}{l}\text { Period of Analysis } \\
\text { and Countries }\end{array}$ & Method & Variables & Conclusion \\
\hline $\begin{array}{l}\text { Liao, Fan and Wei } \\
\text { (2007) }\end{array}$ & $\begin{array}{l}1997-2002 \\
2003-2006 \\
\text { China }\end{array}$ & $\begin{array}{l}\text { Using To"rnqvist and Sato- } \\
\text { Vartia Index methods were } \\
\text { used to determine industrial } \\
\text { energy intensity changes and } \\
\text { sectoral structural effects and } \\
\text { efficiency effects. }\end{array}$ & $\begin{array}{l}\text { Aggregative energy concentration of } \\
\text { the sectors. Energy consumption of } \\
\text { the sub-sectors. Added value created } \\
\text { by the sub-sectors }\end{array}$ & $\begin{array}{l}\text { The results show that in this period, efficiency } \\
\text { effects possibly contributed to a majority of the dec- } \\
\text { line, while the contribution from structural effects } \\
\text { was less. During 2003-2005, the excessive expansi- } \\
\text { on of high-energy consuming sub-sectors and the } \\
\text { high investment ratio were foremost sources of the } \\
\text { increasing energy intensity.. }\end{array}$ \\
\hline $\begin{array}{l}\text { Jansen, } \\
\text { Arkel and } \\
\text { Boots (2004) }\end{array}$ & $\begin{array}{l}2000-2040 \\
\text { Sustainability } \\
\text { Scenarios }\end{array}$ & Shannon Diversity Index. & $\begin{array}{l}\text { Primary energy supply resource } \\
\text { portfolio }\end{array}$ & $\begin{array}{l}\text { Indicators can be used for projections on long term } \\
\text { energy supply security. }\end{array}$ \\
\hline $\begin{array}{l}\text { Frondel and } \\
\text { Schmidt } \\
\text { (2008) }\end{array}$ & $\begin{array}{l}\text { 1980-2004 } \\
\text { Germany and the } \\
\text { USA }\end{array}$ & $\begin{array}{l}\text { A statistical indicator of } \\
\text { Energy Supply Risk Index, of } \\
\text { nations that are heavily de- } \\
\text { pendent on energy imports }\end{array}$ & $\begin{array}{l}\text { Local production and energy } \\
\text { supply.,Economic and political stabil- } \\
\text { ity in the country of origin., Diversifi- } \\
\text { cation of imported energy. }\end{array}$ & $\begin{array}{l}\text { The energy interruption risk of Germany is higher } \\
\text { than the USA due to the concentration of imported } \\
\text { energy resources. }\end{array}$ \\
\hline Gupta (2008) & $\begin{array}{l}2004 \\
26 \text { countries import- } \\
\text { ing oil }\end{array}$ & $\begin{array}{l}\text { Primary Component Analysis } \\
\text { (PCA) and Oil Vulnerability } \\
\text { Index on the basis of various } \\
\text { indicators. }\end{array}$ & $\begin{array}{l}\text { Local oil reserves,net oil import } \\
\text { dependence, diversification of supply } \\
\text { sources, political risk in oil-supplying } \\
\text { countries, and market liquidity. }\end{array}$ & $\begin{array}{l}\text { The most important components in the vulnerabil- } \\
\text { ity index are oil import/GNP ratio, national income, } \\
\text { market liquidity, energy concentration and oil ratio. }\end{array}$ \\
\hline $\begin{array}{l}\text { Shafiee and Topal } \\
\text { (2008) }\end{array}$ & $\begin{array}{l}1949-2006 \\
\text { World and ABD }\end{array}$ & $\begin{array}{l}\text { An ad hoc liner Econometric } \\
\text { model to find out the effect } \\
\text { of variables on fossil fuels } \\
\text { reserve }\end{array}$ & $\begin{array}{l}\text { The ad hoc model use reserves of fos- } \\
\text { sil fuel as the dependent variable and } \\
\text { fossil fuels consumption and prices } \\
\text { as independent variables. }\end{array}$ & $\begin{array}{l}\text { Oil and gas reserves show a positive and significant } \\
\text { relationship with consumption;a negative and } \\
\text { significant relationship with price;coal reserves, } \\
\text { a negative and significant relationship with } \\
\text { consumption;positive and significant relationship } \\
\text { with price. }\end{array}$ \\
\hline $\begin{array}{l}\text { Kruyt et al. } \\
(2009)\end{array}$ & General & $\begin{array}{l}\text { Energy supply security } \\
\text { indicators, } \\
\text { Descriptive analysis }\end{array}$ & $\begin{array}{l}\text { Models based on basic indicators, } \\
\text { indices and scenarios in energy sup- } \\
\text { ply security }\end{array}$ & $\begin{array}{l}\text { Studies that will contribute to the making of the } \\
\text { policies to ensure energy supply security. }\end{array}$ \\
\hline $\begin{array}{l}\text { Jansen and See- } \\
\text { bregts (2011) }\end{array}$ & $\begin{array}{l}2005 \\
27 \text { EU members }\end{array}$ & $\begin{array}{l}\text { Some recent approaches } \\
\text { towards the long-term energy } \\
\text { security measurements Sup- } \\
\text { ply/Demand Index }\end{array}$ & $\begin{array}{l}\text { Fossil fuel dependency. } \\
\text { Energy systems }\end{array}$ & $\begin{array}{l}\text { In the long term, it is important to establish demand } \\
\text { elasticity as well as eliminating vulnerability for } \\
\text { supply security. }\end{array}$ \\
\hline Vivoda (2009) & USA, China, Japan & $\begin{array}{l}\text { A qualitative conceptual } \\
\text { analysis of import resource } \\
\text { diversification }\end{array}$ & $\begin{array}{l}\text { Imported energy diversification. } \\
\text { Energy security of oil importing } \\
\text { countries }\end{array}$ & $\begin{array}{l}\text { While systemic indicators affect each importing } \\
\text { country, the local indicators for each should also be } \\
\text { taken into consideration. }\end{array}$ \\
\hline $\begin{array}{l}\text { Gnansounou and } \\
\text { Dong (2010) }\end{array}$ & $\begin{array}{l}2007-2030 \\
\text { China }\end{array}$ & $\begin{array}{l}\text { A logic-based model on deter- } \\
\text { minants and the indicators of } \\
\text { the vulnerability against the } \\
\text { energy supply disturbances } \\
\text { in China. }\end{array}$ & $\begin{array}{l}\text { Oil, coal and electrical energy supply. } \\
\text { Environmental factors. } \\
\text { Energy Prices. } \\
\text { Qualitative and quantitative analysis }\end{array}$ & $\begin{array}{l}\text { China may reduce } \mathrm{CO}_{2} \text { emission by using newer } \\
\text { technology and using coal to produce electricity. }\end{array}$ \\
\hline $\begin{array}{l}\text { Löchels, Ulf and } \\
\text { Rubbelke (2010) }\end{array}$ & $\begin{array}{l}\text { OECD } \\
\text { Countries }\end{array}$ & $\begin{array}{l}\text { Ex-post. and Ex-ante Indices, } \\
\text { A conceptualize definition } \\
\text { and measure of energy } \\
\text { security via indicators; }\end{array}$ & $\begin{array}{l}\text { Market export potentials and politi- } \\
\text { cal stability of the fossil fuel export- } \\
\text { ing countries. } \\
\text { TPES fossil fuel ratio of the importing } \\
\text { countries }\end{array}$ & $\begin{array}{l}\text { The political stability and market structure of the } \\
\text { energy importing country should be taken into } \\
\text { consideration. }\end{array}$ \\
\hline $\begin{array}{l}\text { Le Coq and } \\
\text { Paltseva (2010) }\end{array}$ & EU Countries & $\begin{array}{l}\text { Oil, Natural gas and Coal } \\
\text { Indices }\end{array}$ & $\begin{array}{l}\text { Energy import diversification, Politi- } \\
\text { cal stability of the importing country, } \\
\text { Risks of energy transit route, }\end{array}$ & $\begin{array}{l}\text { The short term results of energy supply risks are } \\
\text { discussed. }\end{array}$ \\
\hline Cabalu H. (2010) & $\begin{array}{l}7 \text { Asian Countries } \\
\text { Importing Gas }\end{array}$ & $\begin{array}{l}\text { A composite gas supply } \\
\text { security index, composed of } \\
\text { four indicators, for estimation } \\
\text { of gas vulnerability for our } \\
\text { sample countries. }\end{array}$ & $\begin{array}{l}\text { Natural gas intensity,Net imported } \\
\text { gas dependency. Local gas produc- } \\
\text { tion/Total gas consumption ratio, } \\
\text { Geopolitical risks. }\end{array}$ & $\begin{array}{l}\text { The results demonstrate that there are differences } \\
\text { in the values of the overall indicator of gas vulnera- } \\
\text { bility among countries and the assessment is useful } \\
\text { in developing an effective strategy of natural gas } \\
\text { supply security in Asia. }\end{array}$ \\
\hline $\begin{array}{l}\text { Bambawale and } \\
\text { Sovacool (2011) }\end{array}$ & China & $\begin{array}{l}\text { Based on a literature review } \\
\text { and a Survey of Energy Sup- } \\
\text { ply Security in India }\end{array}$ & $\begin{array}{l}\text { Energy supply security, climate } \\
\text { change, geopolitics, self-sufficiency } \\
\text { in energy and trade, decentralized } \\
\text { system, research and innovation. }\end{array}$ & $\begin{array}{l}\text { Fossil fuel supply security in China is the most } \\
\text { important aspect of energy security. }\end{array}$ \\
\hline Greene (2010) & $\begin{array}{l}\text { EU, OPEC and the } \\
\text { world }\end{array}$ & $\begin{array}{l}\text { Oil Security, Metrics Model } \\
\text { (OSMM) includes a linear, lag- } \\
\text { ged adjustment, simultaneous } \\
\text { equation model of petroleum } \\
\text { supply and demand. }\end{array}$ & $\begin{array}{l}\text { Oil dependency. Oil security } \\
\text { The model includes a linear, lag- } \\
\text { ged adjustment, simultaneous } \\
\text { equa- tion model of US, OPEC and } \\
\text { "rest-of-world" petroleum supply and } \\
\text { demand. }\end{array}$ & $\begin{array}{l}\text { Qualitative economic cost in energy supply security } \\
\text { may be reached considering future oil security } \\
\text { policies. }\end{array}$ \\
\hline $\begin{array}{l}\text { Badea, M.Rocco, } \\
\text { Bolado and } \\
\text { Tarantola } \\
\text { (2011) }\end{array}$ & $2005-2030$ & $\begin{array}{l}\text { Building a family of Composite } \\
\text { Index using Weighted Averag- } \\
\text { ing for the security of energy } \\
\text { supply. }\end{array}$ & $\begin{array}{l}\text { Energy and Carbon intensity, Import } \\
\text { independency rate for oil, gas and } \\
\text { coal Primary energy production. } \\
\text { Electric production capacity. Energy } \\
\text { demand by the transport sector. }\end{array}$ & $\begin{array}{l}\text { Indicators in composite index are effective in } \\
\text { determining the precautions to increase energy } \\
\text { supply security. }\end{array}$ \\
\hline $\begin{array}{l}\text { Onat and Bayar } \\
\text { (2010) }\end{array}$ & General & $\begin{array}{l}\text { A Descriptive Analysis of } \\
\text { sustainability Indicators for } \\
\text { power systems }\end{array}$ & $\begin{array}{l}\text { Sustainability parameters in power } \\
\text { production, } \mathrm{CO}_{2} \text { emissions, energy } \\
\text { output, water use, environmental } \\
\text { and social impact }\end{array}$ & $\begin{array}{l}\text { Wind and nuclear energy have the highest sustain- } \\
\text { ability indicators in electricity production and } \\
\text { continuous energy procurement. }\end{array}$ \\
\hline $\begin{array}{l}\text { Balat } \\
(2010)\end{array}$ & Turkey & $\begin{array}{l}\text { Descriptive Analysis of main } \\
\text { challenges of energy supply } \\
\text { security in Turkey }\end{array}$ & $\begin{array}{l}\text { Fossil fuel import dependency } \\
\text { Reliability of energy suppliers. High } \\
\text { energy intensity, Investment in } \\
\text { energy sector }\end{array}$ & $\begin{array}{l}\text { Turkey, can increase its renewable energy supply } \\
\text { especially by its rich thorium resources and with } \\
\text { nuclear energy. }\end{array}$ \\
\hline $\begin{array}{l}\text { Aydin and Acar } \\
\text { (2011) }\end{array}$ & Turkey & $\begin{array}{l}\text { TurGEM-D, a dynamic } \\
\text { multisectoral general equi- } \\
\text { librium model for the Turkish } \\
\text { economy was used }\end{array}$ & $\begin{array}{l}\text { Interest rates, GDP, consumer prices, } \\
\text { inflation, indirect tax incomes, trade } \\
\text { Balance, }\end{array}$ & $\begin{array}{l}\text { Oil prices have a vital impact on the macro indica- } \\
\text { tors of the Turkish economy and carbon emission. }\end{array}$ \\
\hline
\end{tabular}


The energy supply security concern has been effected on the one hand by the local economic, political, social structures; on the other hand some other local or/and global conditions such as wars, embargoes, natural disasters etc. While macroeconomic indices are used for economic risk analysis; The Human Development Index (HDI) is also used in determining political risks factors which have significant effects on supply security (Jansen, 2004; Cabalu, 2010).

\section{EMPRICAL ANALYSIS}

Turkey carried out policy reforms for open economy in the early 1980's. Attributed to the open economy, energy consumption per unit of GDP and total primary energy demand has started to increase slightly since 1980 's. However Turkey does not have sufficient energy and seeks to lessen its import dependency; Turkey's import dependency ratio of is $73 \%, 93 \%$ in oil and $98 \%$ in natural gas, as of 2010 . In future, Turkey should attach more importance to optimizing its energy consuption, and lowering its expenditure on energy imports for sustainable development. The study intends to evaluate the determi- nants of energy supply security (ESS) between 19702009 for Turkey's economy. Following a review of the literature on indices used for measurement of energy supply security and an "ad hoc model" was created. Below various indicators are calculated for the measurement of ESS (ETKB, 2010;OECD,2010).

\subsection{Indicators of Energy Supply Security}

In this study, three different indicators were created for the measurement of ESS. Apart from these, a fourth indicator, which was obtained from the arithmetic mean of the previous three indicators, was also calculated. Table 3.1 indicates the measurement of four-A's (availability, accessibility, affordability, acceptability) dimensions of energy supply and the indicators of ESS.

ESS, index measures the "accessibility" dimension of the energy which means energy supply by any of domestic or foreign sources, without any disruption or delay. ESS ${ }_{2}$ covers both "accessibility" and "affordability" dimensions of the energy supply. Affordability means, energy supply at reasonable price for end users.

Table 3.1.The Dimensions of Energy Supply Security

\begin{tabular}{|l|c|c|c|c|}
\hline Indexes & Availability & Accessibility & Affordability & Acceptability \\
\hline ESS $_{1}$ & & $\mathrm{X}$ & $\mathrm{X}$ & \\
\hline $\mathrm{ESS}_{2}$ & $\mathrm{X}$ & & & \\
\hline $\mathrm{ESS}_{3}$ & $\mathrm{X}$ & $\mathrm{X}$ & $\mathrm{X}$ & $\mathrm{X}$ \\
\hline $\mathrm{ESS}_{4}$ & $\mathrm{X}$ & & \\
\hline
\end{tabular}

Domestic production index $\left(E S S_{3}\right)$ covers the "availability" dimension of the energy supply security. The size or capacity of energy reserves and the production rate of energy source increases the security of energy supply. By means of composite index, security of supply will be evaluated for all dimensions. The composite index (composite/aggregated) approach is widely used in the literature of energy economics to measure definitions which have multi-dimentions (Jansen, 2004; Kruyt et al., 2009; Gnansounou, 2010). The arithmetic mean, weighted arithmetic mean or geometric mean, is a commonly used method for indices or combination of variables (aggregation). In this study the composite index, was obtained by a simple arithmetic mean of all above three indices.

Import Dependency: Energy security index, as one of the frequently used indicators for ESS measurement. Import dependency is defined as the ratio of the sum of the net positive imports over all foreign suppliers to the domestic energy consumption in the country. The amounth and the mix of energy imports, matter for supply security, due to the fact that a high rate of the import dependency on a single energy source, country and/or region have negative effects on energy supply security (Jansen, 2004). It is stated that the diversification of the energy sources, supplier countries/regions, even energy transmission routes or/and lines (such as pipelines or marine transport) increase the security of energy supply (Greene, 2010).

The sustainabile energy supply is of vital importance for the continuity of social life and economic growth. The precautions are taken by governments such as increasing capacity of energy storage, using alternative energy sources as substitute, making possible compensation for energy supply security in the face of short term disruptions.

Import dependency ratio can be calculated by dividing net energy imports to gross energy consumption plus, fuel in international maritime bunkers and expressed as a percentage. If rate has a negative sign; that means there is a "net energy export". If it is 
greater than $100 \%$, this shows that there is "stocked energy". Energy import dependency was calculated as it is given in Eq. 1 (Ediger, 2003).

$\left(E S S_{P}\right)=$ Oil Imports $/ G D P=($ petroleum imports / total oil consumption) $x$ (total oil consumption / total energy consumption) $x$ (total energy consumption / $G D P$ )

The mix of imported energy also matters for supply security. Thus Oil Dependency Index is used as an alternative indicator includes the rate of the imported oil consumption within total energy consumption. It was calculated as it is given Eq.2 (Ediger, 2003);

$E_{S S}(I M P)=$ Energy Imports/Energy Consumption

Energy Intensity: It is defined as total primary energy supply per unit of gross domestic product (GDP) i.e: per US\$1,000 GDP or can be defined also as the ratio of energy consumed per gross domestic product.

It measures the energy efficiency of a nation's economy and expressed by tonnes of oil equivalent (toe). It is calculated as energy use divided by the share of energy for Gross Domestic Product (GDP) as in Eq. 3 (Erdal, 2011);

$E S S_{2}=$ Industrial Energy Use (IE)/Gross Domestic Product (GDP)

Declines in energy intensity are a proxy for efficiency improvements and leads less energy consumption to produce more/same amounth of goods and services. Thus reduced energy intensity accounts for an increase in efficiency and enhance "energy security" by decreasing the amount of imported energy.

Domestic Production Rate of Energy: it is defined as the share of domestic energy production in the total energy consumption. The sheer size of oil and gas reserves the high rate of reserve production, in a country, are acknowledged as indicators of energy independence and as positive factors affecting ESS (Kruyt et.al.,2009:27). The high reserve production rate is explained by the low production costs and have positive effects on energy supply security by providing energy delivery to the consumers, at affordable prices. This rate was calculated as it is given in Eq. 4 (Erdal,2011);

$E_{3 S}=$ Domestic Energy Production / Total Energy Consumption

(4)

Composite Index; a Composite Index, as an alternative and multidimensional indicator for security of energy supply, was calculated from the arithmetic mean of the first three indicators. Composite Index
(ESS $)_{4}$ was expressed as it is given in Eq.5 (Erdal, 2011);

$$
\begin{aligned}
& E S S_{1}: \text { Import Dependency Ratio } \\
& E S S_{2}: \text { Energy Intensity, } \\
& E S S_{3}: \text { Domestic Production Rate of Energy. } \\
& E S S_{4}=(E S S 1+E S S 2+E S S 3) / 3
\end{aligned}
$$

\section{Model and Empirical Results}

In this study, the following ad hoc model is formed, by using the indicators determined by the empirical literature (Gupta, 2008; Kruyt et al., 2009; Jansen, 2004; Gnansounou, 2010; Cabalu, 2010);

$$
\begin{aligned}
& E S_{t}=\alpha(6) 0+\alpha_{1} P P_{t}+\alpha_{2} \text { TPES }_{t}+\alpha_{3} \text { PCCONS }_{t}+ \\
& \alpha_{4} C E M_{t}+\alpha_{5} R E N_{t}+u t
\end{aligned}
$$

Total primary energy supply, total primary energy consumption, total primary energy import, per capita energy consumption, fossil fuel consumption (petrol and coal), fossil fuel energy consumption, renewable energy ratio are measured in terms of energy unit for Tep. (ton equivalent petrol/oil); total fossil fuel $\mathrm{CO}_{2}$ emission is measured in tons; and world oil prices are measured in US dollars. The data for the period between 1970-2009 were collected from the statistics and "General Energy Balance" tables by the Ministry of Energy and Natural Resources, International Energy Agency, OECD and non-OECD countries' energy balance statistics. The Turkish Statistical Institute energy statistics and the British Oil Statistical Review of World Energy 2010 and 2011 (BP,2011;TUIK,2010).

In the emprical analysis, firstly stationarity properties of variables are checked. Then bilateral relations are examined by using Granger Causality tests. Finally the Eq. 6 is estimated by means of Johansen Cointegration Analyses.

\section{Unit Root Tests}

The movement of the two series in the same direction doesn't mean that there is always a significant economic relationship between them. Therefore, the process of data generating, to determine an appropriate model, is very important. In the emprical analysis, initially stationarity properties of variables are checked. 
The Augmented Dickey-Fuller, the Philips-Perron and the KPSS (Kwiatkowski-Philips-Schmidt-Shin) unit root tests, which are commonly used in the empirical literature, were employed in the study.Table 2.3. shows the results of the ADF, PP and KPSS unit root tests. According to results of the ADF and PP tests, security of energy supply variables ESS, $\mathrm{ESS}_{3}$ and $\mathrm{ESS}_{4^{\prime}}$ appear to be stationary at level. But the independent variables do not seem to be stationary at level.
According to the KPSS test, only ESS 2 is found to be stationary at the $1 \%$ level. According to results of each three tests, (all of the tests on the first differences) are found to be stationary. That means the series are cointegrated at level one. Therefore, all series are assumed to be non-stationary in order to avoid from the spurious regression problem, so the cointegration method is preferred for the estimations.

Table: 3.2. Unit Root Test Results

\begin{tabular}{|c|c|c|c|c|c|c|}
\hline & \multicolumn{2}{|c|}{ ADF Test } & \multicolumn{2}{|c|}{ Philips-Perron Test } & \multicolumn{2}{|c|}{ KPSS Test } \\
\hline Variables & Level & $\begin{array}{c}\text { Fist } \\
\text { Difference }\end{array}$ & Level & $\begin{array}{c}\text { Fist } \\
\text { Difference }\end{array}$ & Level & $\begin{array}{c}\text { Fist } \\
\text { Difference }\end{array}$ \\
\hline ESS1 & $-5,411^{* *}$ & $-5,614^{* *}$ & $-5,244^{* *}$ & $-5,788^{* *}$ & $0,205^{* *}$ & $0,732 *$ \\
\hline ESS2 & $-2,589$ & $-7,526^{* *}$ & $-2,589$ & $-7,526^{* *}$ & $0,701 *$ & $0,194^{* *}$ \\
\hline ESS3 & $-3,600 *$ & $-5,613^{* *}$ & $-3,600 *$ & $-5,651^{* *}$ & 0,748 & $0,383^{* *}$ \\
\hline ESS4 & $-5,217^{* *}$ & $-5,663^{* *}$ & $-5,494^{* *}$ & $-5,726^{* *}$ & 0,765 & $0,485^{*}$ \\
\hline IMP & $-2,203$ & $-6,908^{* *}$ & $-3,498^{*}$ & $-7,109^{* *}$ & 0,769 & $0,385^{* *}$ \\
\hline PP & $-2,601$ & $-5,619^{* *}$ & $-2,597$ & $-5,619^{* *}$ & $0,543^{*}$ & $0,233^{* *}$ \\
\hline PCCONS & $-0,672$ & $-5,612^{* *}$ & $-0,674$ & $-5,587^{* *}$ & 0,782 & $0,064^{* *}$ \\
\hline TPES & $-1,498$ & $-6,346^{* *}$ & $-1,547$ & $-6,346^{* *}$ & 0,784 & $0,162^{* *}$ \\
\hline CEM & $-2,178$ & $-4,951^{* *}$ & $-2,263$ & $-4,857^{* *}$ & 0,775 & $0,328^{* *}$ \\
\hline REN & $-0,351$ & $-7,038^{* *}$ & $-0,837$ & $-7,050^{* *}$ & 0,768 & $0,180^{* *}$ \\
\hline \multicolumn{7}{|c|}{ Critical values } \\
\hline$\% 1$ & $-3,615$ & $-3,615$ & $-3,615$ & $-3,615$ & 0,739 & 0,739 \\
\hline$\% 5$ & $-2,941$ & $-2,941$ & $-2,941$ & $-2,941$ & 0,463 & 0,463 \\
\hline
\end{tabular}

Note: Only the results of test including constant term are given. The test results don't change with constant and trend, ${ }^{*}$ and ${ }^{* *}$, respectively, show that levels of, $5 \%$ and $1 \%$ and the null hypothesis was rerejected.

\section{Granger Causality Test}

Granger causality is a statistical test, and used to determine if past values of series may or may not be used to predict future value of another series. If past values of $X$ give significant information about $Y$; it is called as the " $X$ variable Granger-causes $Y$ variable". The following equation is estimated and the null hypothesis $\left(b_{j}=0\right)$ is tested.

To test the hypothesis, the sum of squares of errors from the unrestricted model (RSS $)$, is compared with that of the restricted model by an $\mathrm{F}$ test.

The test results of the Granger Causality (F-statistics), are presented in: Table: 3.3. The results indicate that the total primary energy supply is one of the most important factor explaining the changes in the security of energy supply. Thus the null hypotheses "TPE, is not a cause of ESS " was rejected in all of the above defined five indicators. Also, per capita energy consumption, carbon emissions and rate of renewable energy are some other main factors that have significant effect on energy supply security. The null hypotheses are rejected in accordance with the results of three indicators. Oil prices are Granger-cause of ESS, which measure the energy supply security in terms of external dependence on oil imports (IMP); but are not Granger-cause for the other ESS indicators.

Table: 3. 3. Granger Causality Test

\begin{tabular}{|l|r|r|r|r|r|}
\hline $\begin{array}{l}\text { Independent } \\
\text { variables }\end{array}$ & ESS1 & IMP & ESS2 & \multicolumn{1}{|l}{ ESS3 } & ESS4 \\
\hline PP & $3,615^{*}$ & $3,784^{*}$ & 0,001 & 1,568 & 0,227 \\
\hline TPES & $4,082^{*}$ & $3,969^{*}$ & $3,171^{*}$ & $7,122^{* *}$ & $3,418^{*}$ \\
\hline PCCONS & $6,511^{* *}$ & $3,737^{*}$ & 1,813 & $4,573^{*}$ & 1,513 \\
\hline CEM & $6,108^{* *}$ & 2,598 & $5,430^{* *}$ & $4,623^{*}$ & $3,889^{*}$ \\
\hline REN & $5,435^{* *}$ & $4,989^{*}$ & 1,190 & $5,558^{* *}$ & 2,340 \\
\hline
\end{tabular}

Note: The figures in the cells, shows F-statistics. ${ }^{*}$ and ${ }^{* *}, 5 \%$ and $1 \%$ levels, suggests respectively, rejected the null hypothesis. 
Each analysis 2 delay valuewas used. The direction of causality is from the independent variable to the dependent variable.

One of the interesting results of causality test is that, there is a one-way causality i.e., the causality runs from the independent variables to the security of energy supply,though not shown in the table. In other words, in accordance with the available data and analyses, the changes in oil prices, primary energy supply, per capita energy consumption, carbon emissions and the rate of renewable energy can explaine the changes in security of energy supply. The Granger Causality test, help to determine if there is a bilateral relationship or not..However it cannot give information about the direction of the influence. The regression analysis is a method of characterizing the relationship between two or more variables.

\section{Johansen Cointegration Analyses}

The Johansen cointegration method is used for the estimation of model due to the fact that it is the most widely used method for estimation of non-stationary series. All variables are expressed in logarithm form and a constant term is added to all models. In order to remove serial autocorrelation, one lag is added to the model.Five models are estimated using various dependent variables. Table: 3.4 . shows the results of Johansen cointegration tests. AR roots indicate, that the model is statistically significant, effective and robust. In the model, independent variables explain $80 \%$ of changes in the security of energy supply. Although it is not reported here, the diagnostic tests indicate that there is no sign of autocorrelation (LM test), heteroskedasdisity (White test) and normality (Jarque-Bera test).

Table: 3. 4. Results of Johansen Cointegration Analayses

\begin{tabular}{|c|c|c|c|c|c|c|}
\hline Independent variables & ESS1 & IMP & ESS2 & ESS3 & ESS4 & ESS4-D73 \\
\hline Cosntant & $\begin{array}{l}1,977 \\
(1,757)\end{array}$ & $\begin{array}{l}-3,138 \\
(-3,513)^{* *}\end{array}$ & $\begin{array}{l}-2,439 \\
(-2,663)^{* *}\end{array}$ & $\begin{array}{l}-4,84 \\
(-2,507)^{* *}\end{array}$ & $\begin{array}{l}-0,449 \\
(-0,378)\end{array}$ & $\begin{array}{l}+2,64 \\
(2,647)\end{array}$ \\
\hline PP & $\begin{array}{l}-0,052 * \\
(-2,363)^{*}\end{array}$ & $\begin{array}{l}-0,041 \\
\left(-2,411^{*}\right)\end{array}$ & $\begin{array}{l}-0,003 \\
(0,222)\end{array}$ & $\begin{array}{l}+0,041 \\
(1,171)\end{array}$ & $\begin{array}{l}-0,01 \\
(-0,476)\end{array}$ & $\begin{array}{l}-0,009 \\
(-, 552)\end{array}$ \\
\hline TPES & $\begin{array}{l}+4,009 * \\
(6,414) * *\end{array}$ & $\begin{array}{l}+3,683 \\
(7,937) * *\end{array}$ & $\begin{array}{l}+2,442 \\
(4,797)^{* *}\end{array}$ & $\begin{array}{l}+5,49 \\
(5,391) * *\end{array}$ & $\begin{array}{l}+3,67 \\
(6,099)^{* *}\end{array}$ & $\begin{array}{l}+2,16 \\
(4,416)\end{array}$ \\
\hline PCCONS & $\begin{array}{l}-2,720 \text { ** } \\
(-7,683)^{* *}\end{array}$ & $\begin{array}{l}-1,645 \\
(-6,351)^{* *}\end{array}$ & $\begin{array}{l}-0,849 \\
(-2,811)^{* *}\end{array}$ & $\begin{array}{l}-2,66 \\
(-4,731)^{* *}\end{array}$ & $\begin{array}{l}-1,98 \\
(-5,861)\end{array}$ & $\begin{array}{l}-1,77 \\
(-, 353)\end{array}$ \\
\hline CEM & $\begin{array}{l}-1,788 * * \\
(-4,732)^{* *}\end{array}$ & $\begin{array}{l}1,809 \\
(-6,460)^{* *}\end{array}$ & $\begin{array}{l}-1,809 \\
(-3,634)\end{array}$ & $\begin{array}{l}-2,68 \\
(-4,372)^{* *}\end{array}$ & $\begin{array}{l}-1,75 \\
(-4,815)^{* *}\end{array}$ & $\begin{array}{l}-0,78 \\
(-2,646)\end{array}$ \\
\hline REN & $\begin{array}{l}0,579 * * \\
(4,077)^{* *}\end{array}$ & $\begin{array}{l}+0,243 \\
(2,382) *\end{array}$ & $\begin{array}{l}+0,625 \\
(5,787)^{* *}\end{array}$ & $\begin{array}{l}+0,36 \\
(1,665)\end{array}$ & $\begin{array}{l}+0,40 \\
(3,007)^{* *}\end{array}$ & $\begin{array}{l}+0,10 \\
(0,973)\end{array}$ \\
\hline Dummy73 & & & & & & $\begin{array}{l}-0,72 \\
(-8,494)^{* *}\end{array}$ \\
\hline Trace statistics & $138,542^{* *}$ & $123,555^{* *}$ & $115,568^{* *}$ & $114,753^{* *}$ & $121,697^{* *}$ & \\
\hline Maximum Eigenvalue Statistics & $54,928 * *$ & $50,616^{* *}$ & $45,154^{*}$ & $41,202^{*}$ & $41,996^{*}$ & \\
\hline
\end{tabular}

Note: ${ }^{*}$ and ${ }^{* *}$ coefficients indicate that $5 \%$ and $1 \%$ levels are statistically significant

Both trace statistics and the maximum eigenvalue statistics show that, there is at least one linear relationship between the variables. Oil import dependency is used as an indicator for energy supply security in the second model. According to the results shown in Table: 3.4. an increase in world oil prices, $\mathrm{CO}_{2}$ emissions and in per capita energy consumption adversely affect security of energy supply in Turkey. On the other hand, an increase in primary energy supply and renewable energy comes from natural/domestic sources both have positive effect on security of energy supply. The results are similar to the previous model of ESS is used and are not sensitive to the selected variables. AR roots, as another indicator, support the model.
The energy intensity, as an indicator for security of energy supply, is used as the second dependent variable in the model and defined as units of energy per unit of GDP. It reflects energy consumption in the industrial share of GDP in Turkey. The results (Table:3.4.) show that the model, as a whole, is statistically significant (F-statistic: 11, 558). The independent variables explain 90.7 percent of the changes in the dependent variable in the model. According to the trace statistics and the maximum eigenvalue statistics, the null hypothesis which "there is no linear relationship" is rejected.

Energy intensity is defined as the amount of energy required to produce one unit of output. Similarly The ESS 2 results indicate that energy supply security is influenced by the changes in amounth of 
primary energy supply, per capita energy consumption, $\mathrm{CO}_{2}$ emissions and rate of renewable energy. The model, as a whole, is statistically significant. But, oil prices is statistically insignificant at a level of $5 \%$.

The domestic energy production rate $\mathrm{ESS}_{3^{\prime}}$ as third independent variable in the model is used in order to measure the security of energy supply. The F-statistic shows that the model is statistically significant with $95 \%$ of the R-squared value. Diagnostic tests of the model reveal the absence of autocorrelation and heteroskedasdisity problems.

According to Johansen cointegration analysis, (Table 3.4.) there is at least one linear relationship between the variables in the model. Similar to the previous models, the per capita energy consumption and $\mathrm{CO}_{2}$ emissions have a negative impact on the security of energy supply. On the other hand, when the total primary energy supply increases, the security of energy supply increases in the country. The changes in world oil prices and in the ratio of renewable energy in total primary energy supply do not have a significant effect on energy supply security.

The last model ESS 4 or composite index is composed of the arithmetic mean of three indicators of energy supply security. A composite index is necessary to reduce the disadvantages caused by the data which measure various concepts. The model is statistically significant with an F-statistic of 52.07. The cointegration statistics indicate, that there are at least two linear relationships between the variables. Four variables are statistically significant. It is estimated that an increase in the share of primary energy supply and renewable energy supply in the total energy consumption have a positive impact on the security of energy supply of Turkey. However, the changes in per capita energy consumption and $\mathrm{CO}_{2}$ emissions have a negative effect on ESS. Finally, the security of energy supply is insensitive to world oil prices in Turkey.

In 1973 and 1979 the world has experienced two major crises as a result of sudden elevated oil prices. In 1973 the price of oil per barrel was $\$ 3.29$ and skyrocketed to $\$ 11,583$ in 1974 . Again in 1978, the price was $\$ 14$ and rose to $\$ 32$ (based on annual average Brent oil prices) in 1979. In the 2000's a significant and steady increase in oil prices was observed. Two dummy variables for these crises are added to the model. While The 1973 dummy is statistically siginificant; 1979 dummy is not (Table 3.4.). A sudden increase in oil prices have a negative impact on the security of energy supply. The similar effect is identified for $\mathrm{ESS}_{1}, \mathrm{ESS}_{2}$ and $\mathrm{ESS}_{3}$ models.

Hence, in all of the five models, it is observed, that the security of the energy supply is positively effected by primary energy supply and renewable energy. On the other hand, it is effected negativelly by per capita energy consumption and $\mathrm{CO} 2$ emissions. Having similar results with various dependent variables, it stated that the models are robust.

Oil price is the main determinant of energy consumption because of the fact that, fossil fuels, especially oil, accounts for a significant proportion of world energy demand (35\%) and the oil trade accounts for $60 \%$ of international trade $(B P, 2010)$. High energy prices indicate a high price or cost of GDP and have a negative effect on energy supply security. If oil prices is above competitive market levels, oil consuming economies incur severe costs. The increased energy prices, besides reduced economic output, results in unrequited transfer of wealth from oil consuming to oil producing countries. Energy conservation and efficiency, as a wide range of behaviors and standards, must be part of any energy strategy. Thus, it is necessary to reduce the amount of energy consumption and to invest in new, advanced technologies that decrease energy intensity, which positivelly effect enegy import dependency. It is expected that decrease in energy intensity or efficient use of energy, will reduce energy consumption as well as the cost of production, fossil fuel consumption. On the other hand, some studies suggest that energy subsidies for consumers and industries usually lead to an increase in energy intensity in the long-run. The energy consumption is of vital importance, especially with regards to the economic growth of the developing countries where most of the energy produced domestically is consumed when all other factors are stable. Renewable energy sources, as an alternative to fosil fuels, is used as another indicator, which ensures the security of energy supply. When compared to the fosil fuels, renewable energy accounts for the acceptability of energy source and sustainability in energy supply. The efficient energy use and increase in renewable energy rate will have both a positive effect on the environment for prevention of climate change by reducing greenhouse gas emissions and increasing domestic energy consumption which decrease dependency while increasing the security of energy supply.

According to the Asia Pacific Energy Research Centre (APERC), energy portfolio with zero carbon emission in an economy and shifting from fosil fuels to renewable and nuclear energy in total primary energy consumption, will increase the energy security by increasing the social acceptance (APERC,2009). Both demand and supply of energy in Turkey are in- 
dicators of security of energy supply and has a significant impact on economy and politics. Energy supply must be accessible (available), affordable, reliable and acceptable.

\section{CONCLUSIONS}

Energy plays a key role in terms of industrial production, accommodation and transportation sectors and its regular supply is vital for sustainable economic and social development. The increasing energy demand, all over the world, poses complex challenges for consuming and producing nations. Access to the reliable, affordable energy supplies is a critical factor to improve the life standards in the developing world. The new technologies, address the energy security concerns and environmental issues and they are financed by the oil trade.

The study indicates that the renewable energy positivelly effect supply security in all models. Whatever the definition of energy supply security, it is found that the renewable energy variable is positive and significant. Per capita energy consumption is negatively siginificant in all four models. That is, increasing per capita consumption a risk factor threatening energy supply security in future. Thus, reduction in per capita energy consumption is possible by means of increasing efficiency. The amount of fossil fuel emissions, which runs parallel to energy consumption, is found to be negatively significant in all models and it shows that it is essential to take some measures to reduce emissions to increase both energy security and sustainable development.

The Total Primary Energy Supply (TPES) is an important factor for energy supply security. Because a significant amounth of increase in the energy supply triggers an increase in energy supply security.
The paper empirically analyzed the determinants of energy supply security in Turkey, Although there is problem of data constraints, the main objective of the study has been performed. In the study, unit root and granger causality tests have been used and the contemporary econometric methods of cointegration tests and ordinary least squares. A siginificant outcome of the study, in accordance with the literature reviewed earlier, is that the renewable energy resources is one of the best alternative to ensure energy supply security due to having a positive effect both on energy import dependency and enviroment.

The existing empirical studies mainly have used cross sectional or panel data analyses. In this respect, this study is one of the first time series analyses that specially have been constructed for Turkey. The energy supply security indices ( $\mathrm{ESS}_{1}, \mathrm{ESS}_{2^{\prime}} \mathrm{ESS}_{3^{\prime}} \mathrm{ESS}_{4}$ ), are the unique as they are used in an ad hoc model, which is constructed for Turkey. Hence it is expected that study will contribute much to the empirical literature. Analyses focusing on energy supply security also can be enriched by cross-sectional and panel data analyses carried out in the groups such as the EU, the OECD and in developing economies. Thus, the variables which cannot be added to the model due to the lack of data and quality may be analysed as well. The data that cannot be used in time series analysis due to its intermittent nature such as participation in the international treaties, membership in regional treaties and integrations, wars, political instability, political regime structures and changes, embargoes and terrorism may be examined according to their importance in the political arena. Whereas factors such as the distance to the origin of the imported resource, energy transmission routes and locations and geopolitical location may be analysed geographically. 


\section{END NOTES}

${ }^{1}$ China is now the world's largest consumer of energy at $20.3 \%$ of global energy consumption as of 2012

\section{REFERENCES}

Aydın, L. and Acar M. (2011), "Economic impact of oil price shocks on the Turkish economy in the coming decades: A dynamic CGE analysis", Energy Policy, 39: 1722-1731.

APERC (2009) "Understanding Energy in China, Geographies of Energy Efficiency", Asia Pacific Energy Research Centre (APERC), September 2009. www.ieej. or.jp/aperc.

Badea, A. C., Rocco C. M. S., Tarantola S., Bolado R. (2011), "Composite Indicators For Security of Energy Supply Using Ordered Weighted Averaging Reliability", Engineering \& System Safety, 96: 651-662.

Balat, H. (2010), "Security of energy supply in Turkey: Challenges and solutions". Energy Conversion and Management, 51:1998-2011.

Bambawale M. J., Sovacool B. K. (2011), “China's energy security: The perspective of energy users", Applied Energy, 88:(5): 1949-1956.

British Petrol Statistical Review of World Energy (2010) www.bp.com, (05.03.2011).

British Petrol Statistical Review of World Energy (2011) www.bp.com, (05.05.2011).

Cabalu, H. (2010), "Indicators of Security of Natural Gas Supply in Asia”, Energy Policy, 38: 218-225.

Chester, L. (2010), “Conceptualising energy security and making explicit its polysemic nature", Energy Policy, 38(2): 887-895.

Costantini, V., Gracceva, F., Markandya, A., Vicini, G.,(2007), "Security Of Energy Supply: Comparing Scenarios From A European Perspective", Energy Policy,35: (1): 210-226.

Ediger, V. Ş. (2003), "Classification and Performance Analysis of Primary Energy Consumers During 19801999", Energy Conversion and Management, 44; 29913000 .

Ediger, V. Ş. (2009), “Turkey's Sustainable Energy Development", TÜBA, Günce, Alternative Energy Sources,39; 15-23, [in Turkish].

Erdal L. Determinants of the Energy Supply Security and Renewable Energy Sources As An Alternative, (2011), Adnan Menderes University, Social Sciences Department Of Economics, ECON-PhD-2011-0004, unpublished doctoral dissertation, [in Turkish].

ETKB,2010, "The Republic of Turkey Ministry of Energy and Natural Resources Strategic Plan (20102014)", p. 12, http://www.enerji.gov.tr, [in Turkish].

Frondel, M., Schmidh, C. M. (2008), "Measuring Energy Security- A Conceptual Note", Ruhr Economic Papers, 52:1-19.
Gnansounou, E., Dong, J. (2010), "Vulnerability of the Economy to the Potential Disturbances of Energy Supply: A Logic-Based Model with Application to The Case of China", Energy Policy, 38: 2846-2857.

Gnansounou, E. (2011), "Assessing the Energy Vulnerability: Case of Industrialised Countries", Energy Policy, 36: 3734-3744.

Greene, D.L. (2010), "Measuring Energy Security: Can the United States achieve oil independence?", Energy Policy, 38: 1614-1621.

Gupta, E. (2008), "Oil Vulnerability Index of OilImporting Countries”, Energy Policy, 36: 3: 1195-1211.

Jansen, J.C., Arkel, W.G.V., Boots, M.G. (2004), “Designing indicators of long-term energy supply security", ECN-C--04-007, ss.1-35. ECN Policy Studies, 1/1/2004. ECN report number: Document type: ECN-C-04. http://www.ecn.nl/docs/library/report/2004/c04007.pdf

Jansen J.C., Seebregts, A. J. (2011), "Long-term energy services security: What is it and how can it be measured and valued?" , Energy Policy, 38(4):1654-1664.

Le Coq Chloe' and Paltseva (2009), "Elena Measuring the security of external energy supply in the European Union”, Energy Policy, 37: 4474-4481.

Liao, H. B., Fana, Y., Wei, Y.M. (2007), "What Induced China's Energy Intensity to Fluctuate: 1997-2006", Energy Policy, 35: 4640-4649.

Löschel A., Moslener U., Rubbelke, D.T.G. (2010), "Indicators of Energy Security in Industrialised Countries”, Energy Policy, 38. 1665-1671.

Kruyt B. Vuuren D. P.Van, de Vries H. J. M.and Groenenberg H., (2009),"Indicators for energy security", Energy Policy, 37: 2166-2181.

OECD-2010, Organisation for Economic Cooperation and Development Data on Turkey, http:// www.oecd.org/turkey/, (05.06.2010).

Onat N., Bayar B. (2010), "The Sustainability Indicators of Power Production Systems", Renewable and Sustainable Energy Reviews, 14: 3108-3115.

Shafiee, S., Topal, E. (2008), “An Econometrics View of Worldwide Fossil Fuel Consumption and The Role of US”, Energy Policy, 36: 775-786.

Sohn, I. (2005), "Energy-Supply Security and Energy Intensity: Some Observations from the 1970- Interval”, Minerals \& Energy-Raw Materials Report, 23(4):145-161.

TUIK, 2010, The Turkish Statistical Institute, (05.03.2010).

http://www.tuik.gov.tr/UstMenu.do?metod=temelist

Vivoda, V. (2009), "Diversification of Oil Import Sources and Energy Security: A Key Strategy or an Elusive Objective?", Energy Policy, 37 (11): 4615-4623. 
